\title{
EL CONCEPTO DE DEIDAD EN LAS ANTIGUAS COSMOGONÍAS
}

Contextos para una lectura de Hesíodo ${ }^{1}$

\author{
CÉSAR García Álvarez \\ Universidad de San Sebastián. Chile
}

Resumen: El profesor César García estudia el concepto de Deidad en las antiguas cosmogonías, con especialmente referencia a Hesíodo. Deidad no es lo mismo que dioses: Deidad es aquella cualidad que, a partir del culto de las distintas religiones a sus respectivos dioses, permite abstraer una idea como concepto general común a todas las creencias. Hoy, que con tanta frecuencia se habla de ecumenismo, ésta sería la base conceptual de tales comunicaciones ecuménicas. El concepto general de Deidad comporta diversas cualidades que el profesor García describe en la presente investigación.

Palabras claves: Deidad. Indoeuropeísmo. Hesíodo. Cosmogonía. Cualidades de la Deidad.

\section{THE CONCEPT OF DEITY IN THE ANCIENT COSMOGONIES}

Abstract: Professor César García studies the concept of deity in the ancient cosmogonies, with particular reference to Hesiod. Deity is not the same as gods: Deity is that quality which, from different religions worship their respective gods, can abstract a notion as a general concept common to all faiths. Today, so often spoken of ecumenism, this would be the conceptual basis of such communications ecumenical. The general concept of Deity involves various qualities that Professor García described in the present investigation

Key words: Deity. Indoeuropeísmo. Hesiod. Cosmogony. Attributes of the Deity.

Recibido: 22.11.12- Aceptado: 24.01.13

\section{Correspondencia: CÉSAR GARCíA ÁlvAREz. bizantinoscesar@gamil.com}

Tel. (56-2) 22693878- 22392292. CDoctor en Filosofía con mención en Literatura., de Los Andes y San Sebastián.

${ }^{1}$ Este trabajo es el resultado de un seminario sobre Mitología y Pensamiento Indoeuropeo Griego, dirigido por el Doctor Antonio José de Freitas Goncalves. Universidad de Braga. Portugal. 


\section{ૉ PREÁMBULOS}

\section{El porqué de esta investigación: El Dingir}

Nuestra investigación sobre la Deidad, toma una línea distinta de las de los filósofos: uno es el camino de El dios de los filósofos ${ }^{2}$ y otra muy distinta la de El dios de los mitólogos. Los dos van tras el mismo objeto absoluto y transcendente, pero una es la reflexión sobre la Deidady otra la experiencia de la Deidad. Algunos prefieren hablar de "discurso teológico" frente a "discurso religioso" (el "hieros logos" de los griegos). El "discurso religioso", mitológico, si se quiere -como la vida misma- ${ }^{3}$ es menos estructurado que el teológico, lo que nos lleva a muchas dubitaciones, tantas veces presentes en este trabajo, no obstante trataremos de encauzarlo.

Al examinar diversos textos hititas, sumerios y asirios, nos encontramos con el Dingir que, inmediatamente nos sugirió una investigación más acotada sobre el concepto de Deidad. Era preciso, a la luz de otros textos hititas, sumerios, babilonias, vedas griegos y hebreos, precisar la semántica divina del Dingir, que en otras religiones se expresaba de otro modo: acádico il y en semita ' $i l^{-4}$.

Pero ¿qué es el Dingir?: Es un signo cuneiforme, con carácter de determinativo que indica poder sobrehumano con sentido positivo, y es sinónimo de Deidad. El Dingir no se pronuncia, y se translitera convencionalmente como superíndice "D". Significa con sentido positivo dios, diosa, cielo, algo numinoso que pertenece a otra esfera distinta de la nuestra, lo traducimos e investigamos como Deidad. Para Rochberg 5 , se trata de una marca lingüística con función clasificatoria: en

${ }^{2}$ Wilhelm Weischedel. (1983) Der Gott der Philosophen. Wissenschaftliche Buchgesellschaft, Darmstadt.

${ }^{3}$ Pensemos que en Israel, Yahveh es un Dios de la historia, mucho menos que el que nos dan las definiciones teológicas.

${ }^{4}$ Edzard, Dietz Otto (2003). Society of Biblical Literature. ed. Sumerian Grammar. Handbook of Oriental Studies. 71.

5 "Constructions of the Divinity: Thoughts on the Notions of God in the Ancient Near East".(1999 Diálogos. (Harvard). 
una clase se marcan con el Dingir diversos tipos de cosas. En el caso del Dingir en la lengua hitita, ya no se habla de un dios más, sino de la Divinidad o, para ellos, de algo sobrenatural, como en la invocación en el induismo a Visve Devas (a todos los dioses) es a la Deidad, a lo divino, para no olvidarse de ninguno de los dioses, no sea que se enojen. Eso lleva inmediatamente a la objeción que plantea Porter: Pero en la antigüedad ¿qué dios era realmente dios por definición? ¿quién encarnaba mejor la idea de Deidad?

El ideograma del Dingir fue una estrella y no se modificó desde el 3.200 a.C. al 600, lo que nos sugiere una de las primeras características de la Deidad, su inmutabilidad o persistencia, que va mucho más allá de la representación ideográfica; si hay una constante en la tradición indoeuropea, es precisamente la de lo sagrado, signado con el Dingir. Esto nos lleva de la mano al cuerpo de esta investigación: determinar los rasgos con que el mundo indoeuropeo designa la Deidad, y su proyección hasta alcanzar a Hesíodo.

\section{Mundo indoeuropeo y tradición}

El mundo europeo fue intensamente celoso de su identidad; para ello estableció instituciones protectoras de su cultura, y una ética de su continuidad; una de estas instituciones fue el pacto: Mitra, Týr son dioses del pacto. Romper un pacto en su mitología, es provocar un cataclismo. Romper el pacto es uno de los cuatro pecados capitales del indoeuropeo, señala J.Ward. El pacto, ciertamente, da continuidad. La segunda institución protectora de identidad indoeuropea fue la tripartición social, una estructura ordenada en tres ámbitos: jurídico-mágico, militar y de subsistencia. Se podrá decir que esta estructura es universal, la singularidad indoeuropea se encuentra en que eran hombres de orden, con rigurosa conciencia de ser fieles a estos ámbitos. La tercera institución preservadora de identidad fue la patriarcal, la de la preeminencia de la familia, con sus proyecciones en la valoración de los orígenes (mitos), a Dios como primer Padre, y al culto de los antepasados. La cuarta institución, la dignificación del mundo agrario: no digamos que el indoeuropeo era sedentario, pero tampoco existía en ellos sangre con afanes de conquista de otros espacios. El mundo marino, siempre desidentificador, no les era familiar, como leemos en Boyer. La quinta fuerza de continuidad indoeuropea fue su poder de la lengua. Gracias a esta cohesión lingüística, se ha podido establecer con bastante precisión el árbol genealógico de los idiomas indoeuropeos, un diccionario afín, una fraseología coincidente, motivos comunes en los cuentos 
populares, mitos persistentes como el del dragón cuya bibliografía es inacabable ${ }^{6}$ y esquemas cercanos con respecto a géneros literarios; todo ello, porque el indoeuropeo se habló hasta el quinto milenio de nuestra era, su influencia en los extremos de Europa, la Península Ibérica, fue hacia el 3.000 a.C. y, ciertamente, hacia el año 1.000 desde España, Islas Británicas hasta Bengala se dio una zona plenamente indoeuropeizada ${ }^{7}$. Finalmente, motivo de esta persistencia indoeuropea es lo que Boyer llama la "Gloria", el ser digno de pasar a la historia y que recogen las estrofas 76 y 77 de los Hávamál, en la Edda poética:

$$
\begin{gathered}
\text { Mueren los bienes, } \\
\text { mueren los padres, } \\
\text { tú, también tú morirás } \\
\text { Pero la reputación } \\
\text { no muere jamás, } \\
\text { la buena reputación que se ha obtenido }{ }^{8} \text {. }
\end{gathered}
$$

Todo esto no es óbice para que podamos entender, en el desarrollo e influencias indoeuropeas estratos y superestratos de encuentros con las mismas ideas indoeuropeas: adopción, implantación, asimilación, transplantes, recreación, refundición, y todas las formas con que las culturas se entrelazan, sin que se pierda su continuum: La historia de la cultura nos dice que las semejanzas culturales son siempre más persistentes que las diferencias.

\section{¿Qué es la Deidad?}

La Deidad, del latín “deitas" es una cualidad de los dioses, y como tal también es una cualidad del Dios mismo de la fe cristiana. Para San Agustín, toda vez que Deidad, de "Deus", fue una palabra creada por los apologistas cristianos, teniendo

\footnotetext{
${ }^{6}$ Prescindimos de la referencia al dragón en la China, que, como animal de los cuatro elementos: del aire (vuela), de la tierra (se arrastra), del agua donde a veces se oculta, y que, se creía, lanzaba fuego por su fauces, era símbolo del Emperador y tenía, en consecuencia, un signo positivo; el dragón indoeuropeo, es negativo, encarna el poder del Mal. Una de las primeras representaciones puede verse en el Museo Civilización de Anatolia. Ankara. Turquía: Aquí DIm da muerte al dragón Ulliyanka.

7 La Dialectología, con sus estudios sobre las reglas de derivación fonética de las palabras, desde el indoeuropeo al rotogriego, primero, al lésbico después, para dar en el dórico y ático -por ejemplo- nos confirma esta continuidad lingüística, y nos resuelve muchos problemas de la poesía de Safo escrita en eólico, dialecto griego tan cerca del hitita y lubita. Hoy se dice que existe un setenta de probabilidades que en Troya, la Troya de Homero, hablaba lubita, un idioma indoeuropeo hermano del hitita. Por cierto, existe consenso que el griego del siglo X a.C. era muy parecido a la lengua hablada en Irán.Hacemos hincapié en esto, pues, la continuidad lingüística es el cauce de la continuidad de la cultura. Puede verse Meillet, A. Introduction á l' étude comparative des langues indo-européennes. París, 1937.

8 Traducción de Régis Boyer, en El Mundo Indoeuropeo". En Tratado de antropología de lo sagrado(2). El hombre indoeuropeo y lo sagrado. Edit. Trotta. Madrid. 1995, pág. 38.
} 
en cuenta la palabra griega "theotes", esencia divina, no puede aplicarse a todos los dioses. Diferimos de este concepto, a partir de los estudios etimológicos del indoeuropeo, como después aclararemos. Hoy la Enciclopedia Católica registra dos términos distintos, uno para Deidad y otro para Dios (Driscoll, John T. "Deity").

Deidad es un término de la nueva ciencia de las religiones. Esta ciencia parte del principio que la religión es un fenómeno universal de la humanidad, como señala Micea Eliade; lo religioso es un elemento estructural de la propia conciencia. En esta ciencia de las religiones, la Deidad no es persona divina. La Deidad es una idea de la inteligencia humana, idea que trata de universalizar todo aquello en que participan todos los dioses, de cualquier religión que sean, ya sean creados por el hombre o revelados. Los pueblos religiosos no se preguntan si la Deidad es "epifánica" o "bierofánica"; simplemente, es algo numinoso. Incluso en el panteísmo, la Deidad no es persona, aunque actúe como persona; los árabes precisamente reservan el término ilāh (ل) para hablar de Deidad en general. Recordemos que en el hinduismo, el Uno, la Unidad, que está sobre todos los dioses y nosotros, es la Deidad: no es persona, se expresa en neutro o con el pronombre demostrativo neutro tad (esto), así como los griegos oponían el Uno (to on) a los dioses (oi theoi), el término griego theion, en lugar del sustantivo theos, implicaba así mismo una abstracción, acaso por ello Aristóteles habla siempre de lo "divino" y no de los dioses, y los cristianos distinguimos entre Dios y en neutro lo Divino, que es la Deidad.

Para hablar de la Deidad no nos preguntamos "qqué es un Dios personal"? porque esto es ya otra cosa, esta pregunta nos fija un marco que nos obliga en cierto modo a una respuesta obligada, como observó Rochberg ${ }^{10}$. La palabra Dios me lleva comúnmente- por razón de la persona divina- a una lógica configuración humana: Dios es persona y está dotado de nuestras cualidades, solo que en grado sumo: Ser Sumo, Bondad Suma, Verdad Suma, Justicia Suma etc; pero el concepto de Deidad es otra cosa, sin que niegue la anterior, antes bien le dé una mayor potencialidad. Esta es la razón por la que en este ensayo, en ocasiones, acercaremos la palabra Deidad a Dios o la esencia misma de Dios. Hablar de Deidad, requiere comúnmente un lenguaje menos acotado que hablar de Dios, aún siendo Dios, Deidad. La Deidad, para concluir este acápite, es un "estado" de algo singularizado por una acción numinosa

${ }^{9}$ The Catholic Encyclopedia (1908), Vol. 4. New York: Robert Appleton Company.

10 "Constructions of the Divinity: Thoughts on the Notions of God in the Ancient Near East" (1999).

Diálogos. (Harvard). 
(nouménico) una singular potencialidad, así como la beldad no es la belleza ni la igualdad es lo igual ${ }^{11}$-aún suponiendo la belleza y lo igual- pero beldad e igualdad son manifestaciones de un antecedente, así la Deidad es expresión de Dios. La Deidad es sinónimo de Sacralidad, algo que se manifiesta en el templo, término que se entiende mejor por oposición a Profanidad (pro-fanum, ante el templo). La Sacralidad como la Deidad reclaman, dentro del templo, el sacrificio, sacrum - facere, hacer algo sagrado. La Deidad es la sacralidad. En la teología cristiana el Dios Padre, Dios Hijo y Dios Espíritu Santo, no son la Deidad, la Deidad serían las procesiones: en la esencia divina viva, activante, se encuentra la Deidad.

La Deidad, en la historia de las religiones, es una actividad o manifestación intrínseca de los dioses, que se derrama después a la creación a través del sacrificio. No hay religión sin sacrificio, incluso en la mitología más abstracta: precisamente en la Teogonía de Hesíodo, Zeus no alcanza la justicia cósmica -hablaremos después de ello- sin el sacrificio de Cronos. En el cristianismo, en el pan y el vino se une la Deidad a la creación. En definitiva: en todo sacrificio la Deidad se derrama en el acto mismo del sacrificio, vinculando ofrenda, sacrificador y comunidad con el axis mundi, sinónimo de Deidad ${ }^{12}$.

En el mundo védico, para el sacrificio, se elige el terreno para el culto, se delimita haciendo un surco con un arado mientras se ora: entonces lo sagrado y lo profano se separan, nadie debe osar atravesar el surco, si no es por ciertas puertas; entonces, el lugar propicio para la Deidad está dispuesto ${ }^{13}$. No es el aquí el dios el que se hace presente, es su potencia deifica. En el hinduismo, para clarificar un poco más el concepto señalado, se distingue claramente el ser y la función: un dios por ser un ente vivo se manifiesta, esta manifestación vital procedente de un dios, y que lo define, es la Deidad; ¿qué es en el mismo hinduismo Indra sin Indriani, el patrón de la guerra sin el poder de la guerra? Una es la vida, otra el que la vive; la Deidad es la vida, los dioses son los que la viven, son más sujeto que acción. Todas estas distinciones, por cierto, hay que entenderlas en el orden del conocer, pues en las religiones más depuradas, judeo-

${ }^{11}$ Esto es lo que en el hinduismo a veces nos confunde, pues lo sagrado para ellos es personificado.

${ }^{12}$ No se me pasa inadvertida la tesis de los sociologistas, como la de Bermejo Barrera, para quienes mito y religión son reductibles a un acercamiento de una comunidad y su identificación: esto no resuelve el porqué esas fiestas comunitarias se convocan en torno a un hecho religioso. José Carlos Bermejo Barrera, Introducción a la Sociología del Mito. Madrid. Akal. 1994.

${ }^{13}$ No es necesario recordar la herencia indoeuropea de la fundación de Roma, allí donde Remo osó atravesar el surco sagrado, y que pagó con su muerte. 
cristianismo y mundo védico, lo Divino goza de una esencial simplicidad, que no admite separaciones ${ }^{14}$. El problema que planteamos debe ser puntualizado, para no elevar el concepto de Deidad a una mera abstracción.

Las conceptuaciones de Deidad, como ya estamos apuntando, varían según las religiones; en nuestro caso, vamos a centrarnos en un estudio comparativo de las religiones primitivas indoeuropeas: hititas, sumerios, acadios, babilonios, védicos, alcanzando incluso a Grecia y en cierto modo al mundo semita. El patrimonio cultural indoeuropeo, hasta ayer restringido ${ }^{15}$, hoy se ha abierto también a las religiones, después de los estudios comparativos llevados a cabo por J.Vendryes (1875-1960) y de Georges Dumézil (1898-1986) ${ }^{16}$. Entre los rasgos comunes a estas religiones se encuentra un particular acento en las cosmogonías y escatologías, forman ellas un corpus muy definido que nos va a llevar a alcanzar algunas características comunes sobre qué sea la Deidad.

\section{ALGUNOS RASGOS DEFINIDORES DE LA DEIDAD}

\section{1.- Comunicabilidad}

Toda Deidad es en sí y para los hombres; la Deidad tiene, por tanto, una función, además de autónoma por ser Absoluta, política, religiosa, social o aglutinante de un grupo. La expresión de ello son las procesiones: Panatenaicas en Grecia; en los hititas el traslado de la imagen de Siu; en el cristianismo

${ }^{14}$ Sobre esta prevalencia de la Unidad (eka, Isvara, Prajapati) -que asimilamos a Deidad- sobre la tríada védica Siva-Visnú-Brahma, véase: "La India y los Sagrado", de Jean Varenne, en Tratado de antropología de lo sagrado: El hombre indoeuropeo y lo sagrado. Madrid. Trotta, 1990, pág. 103.

${ }^{15}$ No será necesario recordar el famoso discurso pronunciado en 1789 por W. Jones (1746 - 1794) ante los miembros de la Royal Asiatic Society de Calcuta, en el que demostró la existencia de un antepasado común indoeuropeo; discurso que abrió las puertas a futuras investigaciones comparativas en los campos de la lingüística, antropología, pensamiento arcaico, literatura, arte, más tarde al mito y la religión.

${ }^{16}$ La zona del Oriente Medio fue culturalmente de una gran ebullición de influencias: los escribas hititas conocían varias lenguas; por otra parte, el comercio de la zona fue intenso y se vendía junto a especies, textos y tablillas. Entre los hititas y egipcios se encuentran cartas políticas en uno y otro idioma; por otra parte, existen tablillas hititas que mencionan, por ejemplo, a los dioses griegos Apolo, Hera, Kronos, y se exhibe en el museo hitita de Hatusa una espada de bronce que dicese ser de Príamo. Son abundantes los estudios que nos hablan de las vinculaciones entre el mundo hitita y el mundo micénico, particularmente en lo que se refiere a la estructura social. No es necesario referirse a Chipre: el griego chipriota, del siglo X hasta el II a.C. se escribió en jeroglíficos, junto con el griego alfabético. Hesíodo, al que nos vamos a referir con frecuencia, dice en Los trabajos y los días que su familia procedía de Asia Menor, lo que nos lleva a pensar que su Teogonía no es ajena a la de aquellas tierras de sus antepasados, particularmente en lo que se refiere a la sucesión de dioses (Gaia, Urano Zeus etc.) de origen reconocidamente hitita. Acaso el ejemplo mejor de esta globalización se encuentre en esta frase del mito hitita El Dios perdido: "GU-ma AMAR-SU mi-im-ma-as" (y la vaca abandonó a su cría), (GU: sumerio; ma: hitita; AMAR : sumerio; $S U$ : acádico; mi-imma- as:hitita) ¿El idioma de Troya, no era el lubita? 
las entronizaciones; entre los vedas la procesión del Ratha Yatra; entre los judíos la Ghriba o cuando la Torá se venera en una procesión. La Deidad se da a los hombres, la palabra "diew" en indoeuropeo aparece asociada con frecuencia a "pater": dyeu-pater, en sánscrito dyaus pitar y en el cristianismo "Dios Padre”, en griego "Zeus Pater" que dará en latín Júpiter y la paternidad lleva necesariamente implícita la idea de filiación o comunicación amorosa. En el "Himno védico sobre la creación" se lee: "El deseo (el amor) surgió en el principio", la Deidad es amor ${ }^{17}$, radicado en el Gran Padre y la familia, institución fundamental en el mundo indoeuropeo, que algunos han llamado incluso "familiolatría" ellos la idea de Deidad; no obstante ello, la noción de Deidad como Pater está en ellos familiarmente, muy arraigada.

Cuando citamos al mundo védico, debemos tener en cuenta su preeminencia significativa en la historia vinculante con el indoeuropeo: cuarenta siglos lleva la permanencia de esta religión védica, al lado del judaísmo (30 siglos), el budismo (25 siglos), el cristianismo (20 siglos) y el islam (12 siglos). El aislamiento, si no desprecio del mundo védico por occidente, no ha perjudicado a la India, ha empobrecido a occidente.

Hemos deslizado la palabra amor como sinónimo de Deidad. El tema del amor en el mundo indoeuropeo y en la configuración de la idea de Deidad, es sumamente interesante: ¿Qué es eros, esta entidad que aparece como un elemento activante en todas las cosmogonías? Se hace presente entre Gaya y Urano para la generación de la teogónica, en Safo se mezcla con todo y aparecen Urano, Océano, Tierra, los Bienaventurados dioses y toda su generación ${ }^{19}$; tal vez el canto más hermoso al amor y su poder, se encuentre en el Libro V de El Asno de Oro de Apuleyo: el amor, por ser Deidad todo lo mueve y de su sublimidad es que este amor no se deja ver. Advirtamos, antes de pasar adelante, que sobre este gran tema: Amor y Deidad, no vamos a hacer una larga parada reflexiva, pues cuanto digamos, tendrá la condición de ser un pequeño hilo de afluente que conduce inexorablemente al gran cauce del río que es Amor y Deidad.

17 Puede verse: Roberts, Edward A. y PAstor, Bárbara. «deiw-». Diccionario etimológico indoeuropeo de la lengua española. Alianza. p. 34.

${ }^{18}$ Boyer, RÉGIs.(1995) "El mundo indoeuropeo", en Tratado de antropología de lo sagrado. Edit. Trotta. pág.26. Madrid.

${ }^{19}$ Hieros-Logos. Poesía órfica sobre los dioses, el alma y el más allá. (2003). Ed. de Alberto Bernabé. Madrid, Akal Clásica. 


\section{2.- "Deus absconditus"}

La Deidad, no obstante su don de comunicabilidad, ama ocultarse. Los designios de Dios son insondables ${ }^{20}$. La comunicación de la Deidad es siempre misteriosa, se restringe, el hombre no puede acceder a ella cara a cara, cuando Psiqué descubre el rostro de Cupido, éste desaparece; era condición necesaria de la felicidad de Psiqué no ver el rostro de su amado ${ }^{21}$. La Deidad excede lo natural. El origen indoeuropeo "deiw", significa brillar o blanco, pero como epíteto es el brillar sustancial, que ciega, es el medio día divino"22; de Deidad se deriva en latín "dies", cuando aparece la luz; cuando en el cristianismo se dice "Dios es la luz del mundo"23 no se refiere a nuestra luz natural, es una luz sobre toda luz ${ }^{24}$.

La Deidad, como ocultación o luz que ciega, no se la puede definir, sino invocar; Deidad significa precisamente "adoración", a ello nos lleva la raíz indoeuropea "ghau(e)", que es invocar, de donde deriva "ghutóm" y de aquí "god" en inglés y "gott” en alemán, que recogen la idea de invocación: La Deidad es el Ser que se invoca. El término teutón antiguo "ghuba» implica la misma raíz. Añadiremos algo más: Hay dos raíces arias de la forma requerida («g,heu-» con palatal aspirada), una de las cuales significa invocar (sáns. «hu») y la obra libar,

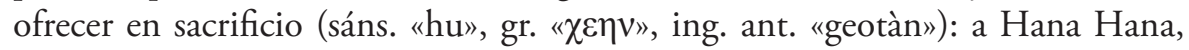
entre los hititas, nadie le hace oraciones de petición, sino de invocación, como tampoco a Brahma, por ser el dios primordial, fascinante; en el texto hitita la Proclamación de Anita ${ }^{25}$, muy importante por tratarse del texto más cercano al indoeuropeo, Siu es dios, pero al colocarle un determinativo (D), nos viene a decir, que es el dios más importante o de la fascinación.

En hebreo, el nombre de Dios no se pronuncia, es "El que es, el que vive" (Adonai); algo similar sucede con la Bona Dea de los ritos místicos latinos, cuyo nombre tampoco se pronuncia. En la religión babilónica-asiria, como señala Saussaye: "Entre las palabras influyentes que podrían evitar o expulsar el mal, las más

${ }^{20}$ Salm: 92.5 .

${ }^{21}$ Véase L.V de El asno de oro de Apuleyo. Incluso la manifestación divina del palacio de Cupido hace aparecer vinos, comidas exquisitas, se escuchan músicas, pero nadie ve quién canta o sirve. Amor y Muerte es un gran tema que no vamos a desarrollar aquí.

${ }^{22}$ El lector tolerará esta metáfora, pues en lo divino, en lo perfecto, no existe un antes ni un después más perfecto. como el centro del día.

${ }^{23}$ JUAN 8,12.

${ }^{24}$ Los hebreos no son indoeuropeos, no obstante ello, los vinculamos culturalmente con los hititas, pues fue un pueblo que no les fue ajeno: Las referencias en la Biblia sobre los hititas las encontramos en Josué $(3,10)$, Génesis $(15,19-21)$, (23,3) Números $(13,29)$ y Libro II de los Reyes $(7,6)$.

${ }^{25}$ Larroche, E. (1971). Catalogue des textes hitities (París, Klincksiek). 
destacadas eran los nombres de los grandes dioses; pero estos nombres se consideraban secretos, y por lo tanto la gente apelaba al dios mismo para que lo pronunciara"; en Grecia, Herodoto dice que los dioses pelásgicos no tenían nombre. Finalmente, entre los vedas existe un árbol sacrificial al que se le honra de este modo: “ $\mathrm{O} O \mathrm{~h}$ árbol, como tú sabes los nombres sagrados de los dioses, haz que las ofrendas vayan a ese lugar". Nos lo advertía la Sagrada Escritura, al hablar de nuestras limitaciones: "Porque mis pensamientos no son vuestros pensamientos, ni vuestros caminos mis caminos, dijo Yavveh. Como son más altos los cielos que la tierra, asi son mis caminos más altos que vuestros caminos, y mis pensamientos más que vuestros pensamientos" 26 . En hebreo, también otros idiomas, existe una vocal inefable", la $a$, Aleph, símbolo de Dios y que no puede ser articulada, pues la a se expresa inicialmente abriendo la boca, sin aspiración; ¿cómo transmitir a los otros el infinito Alehp? dice Borges. El hombre puede "decir", un grado más "cantar", pero para la Deidad se reserva la palabra "celebrar". Celebrar supone comunión con la Deidad, aquello que expresa San Juan de la Cruz al decir: "Quedeme y olvideme"27; algo que en el hinduismo está muy presente en cualquier oración, ofrenda o rito: no condiciona la Deidad, que es un Ser Absoluto, al que el ser relativo no puede exigir. Por lo mismo, Homero, a diferencia de Hesíodo, canta a los dioses, pero no los explica. Las palabras de Ortega son en esto sorprendentes: "Mas lo peculiar de Dios es que al citarlo como testigo en esta nuestra relación con la realidad que consiste en decirla, esto es, en decir lo que realmente es, Dios no representa un tercero entre la realidad y yo. Dios no es nunca un tercero, porque su presencia está hecha de esencial ausencia; Dios es el que es presente precisamente como ausente, es el inmenso ausente que en todo presente brilla-brilla por su ausencia- (...) El maestro Eckehard -el más genial de los misticos europeos- llama por eso a Dios él silente desierto que es Dios"28; por ello en el mundo semita noroccidental el "discurso religioso" es el "himno", la "súplica”, la "lamentación” y el "oráculo profético", formas no discursivas, aclaratorias, ajenas al "discurso teológico", y bien alejadas de rigurosos formularios socializados. La Deidad en este sentido no depende de la religión, del decir común (rito), no es de su esencia el religare”, pues la Deidad es un ser en acto.

En el hinduismo el Absoluto (brahman), es solitario (kevala), único (eka). El Vedanta enseña que el creyente puede y debe mediante un ejercicio interior (kriya -trabajos-; tapas -ascesis-) arrojarse a la unicidad del brahmanlatman, que hemos

${ }^{26}$ IsAíAs 55:8-9).

${ }^{27}$ San Juan de la Cruz. Último verso de Noche Oscura del Alma.

${ }^{28}$ Ortega y Gasset, J. (1963). Obras Completas. Ed. Revista de Occidente. Madrid, Vol.VII. pág. 145. 
llamado el Absoluto de la Unicidad o la Deidad, llegar a la Nostalgia del Uno. El mundo pende de este núcleo, Uno, Principio, Deidad, de lo sagrado, pero esta Deidad se esconde y solo se da por vía vital al que lo busca. En el arte hinduista, el fiel después de venerar al Absoluto en la imagen, debe olvidar ésta para saltar a la unidad plenificante de la Deidad misma, cuyos signos se silencian ${ }^{29}$. Heráclito, tan lejos y tan cerca del mundo védico -Éfeso fue colonia hitita- escribe: "Es sabido que, aquellos que han escuchado al Logos, no a mi, convengan en que todo es uno»" ${ }^{30}$.

No obstante lo anterior, existe un esfuerzo de los hombres por conocer este Uno, la Deidad, y nombrarla: Siu para los hititas, Zeus para Hesíodo, el Ser para Parménides, el Sumo Bien para Platón, Dios para los cristianos ${ }^{31}$. El indoeuropeo, común a todos estas culturas, nos facilita desde el punto de vista etimológico el problema del nombrar, porque pareciera que se trata del mismo nombre: Siu>Zeus $>$ Deus $>$ Dios. En ocasiones, el mismo concepto toma nombres distintos según se manifieste. J. Danielou ${ }^{32}$ señala las distintas manifestaciones y nombres de Dios en la historia: primero en forma cósmica ("Dios de los cielos"33), después por los profetas ("Dios de los profetas"34), finalmente por su Hijo ("Dios, al fin de los tiempos, se manifestó a través de su Hijo"35) y hoy se manifiesta en la Iglesia ("Estaré con vosotros hasta el fin de los tiempos"36) sin que esta secuencia sea excluyente, más bien acumulativa, por eso los cristianos, seguiremos alabando la naturaleza, leemos a los profetas, confesamos a Cristo como Hijo de Dios y su presencia en la Iglesia. Este carácter nominativo cambiante de la divinidad cristiana-hebrea, pareciera ser otro rasgo de la Deidad; como dicen los musulmanes, Ala es el Dios de los Mil nombres, 99 nombres: "Dios tiene noventa y nueve nombres, cien menos uno. Quien los cuente entrará en el Paraiso"37.

${ }^{29}$ Delahoutre, Michel. (1990). "Sacralidad y estética en el arte de la India", en Tratado de antropología de lo sagrado. El hombre indoeuropeo y lo sagrado. Madrid. Ed.i. Trotta. 1990. pág. 124.

${ }^{30}$ Heráclito. Fragmento 50, Diels.

${ }^{31}$ Santo Tomás destina toda la Cuestión 13 de su Suma Teológica (Ed. BAC. 2001) a dilucidar el problema de Los Nombres de Dios. Una reflexión filosófica, teológica y filológica que aborda, como todos sus asuntos, con una sabiduría casi inspirada.

${ }^{32}$ Danielou, J. (1996). Dios y nosotros. Ed. Taurus. Madrid.

${ }^{33}$ Nehemías.2.20.

${ }^{34}$ Hebreos.1.1.

35 JUAN.1.14.

${ }^{36}$ Mateo. 28.19.

37 Todos estos 99 nombres se encuentran el Corán: algunos se citan sólo una vez (El dispensador de bienes, El Victorioso, El Custodio), otros salen frecuentemente (El que oye, 47 veces; El Vidente, 51 veces), y algunos se repiten incansablemente, como el Misericordioso (115 veces). 
Merece la pena recordar aquí la Teología Mistica ${ }^{38}$ del Pseudo Dionisio, y que se inicia en el capítulo I con este título: "En qué consiste la divina tiniebla".

Una de las cualidades de la Deidad como "Deus abscónditus", es que desaparece, se pierde. El mito de "dios desaparecido" es recurrente en la historia de las religiones indoeuropeas: Ello nos habla de restauración o recreación como actividad propia de la Deidad. Aquí las diversas religiones, particularmente indoeuropeas, despliegan un amplio espectro de ocultaciones y manifestaciones de sus dioses: Recordemos el mito hitita de Telipinu o el dios desaparecido, llevado a Anatolia por los indoeuropeos y con claras influencias en Dionisio y Perséfone en Grecia, dioses también desaparecidos o del descenso. El mito hitita está escrito, además de lenguaje hitita, en acádico y sumerio. Alguien molestó al dios hitita, no sabemos la causa, pues el comienzo de la tablilla está rota, solía ser la parte más frágil de las tablillas, así como los lados. Tal molestia con característica de grave pecado, hizo que toda la naturaleza quedase afectada como por un cataclismo, y el dios huyó y se ocultó en un lago entre unos cańaverales (¿infierno, hades, sheol, submundo? Era preciso buscar al dios del enojo y el poder fecundante de la naturaleza, pues todo estaba agostado. Telipinu e Inana entre los hititas, como Cronos, Perséfone y el poder del Vellocino de Oro entre los griegos, son dioses con poder sobre la recreación manifestada en las cosechas. Tras ofrendas, oraciones ${ }^{39}$ y ensalmos, Telepinu volvió y comenzó la restauración del mundo.

La Deidad que huye, baja al submundo o katábasis, no parece sino que, por la reiteración del mito ${ }^{40}$, acusa también como señalamos una cualidad de la Deidad. La Deidad vuelve y comienza; en términos de San Pablo opera una "reintegratio mundi", una restauración cósmica y antropológica. El texto de Safo dice "Theos egenou es anthropou"("devienes dios, desde los hombres"), que nos recuerda aquello de San Atanasio ${ }^{41}$ : "Dios se hizo hombre para que el hombre se haga Dios".

El mito del "dios desaparecido" pude tener varias lecturas ¿un mito literario que satisface la imaginación y nada más? ¿significación del ciclo natural de las

Todos los musulmanes conocen este hadiz transmitido por Abu Hurayra: "Dios posee 99 Nombres, Cien menos Uno, porque Él, que es el Incomparable, desea ser invocado por esos Nombres, uno a uno. El que conoce esos 99 Nombres entrará en el Paraíso".

${ }^{38}$ Pseudo Dionisio Areopagita, (1995). Obras Completas: Los nombres de Dios. Jerarquía celeste. Jerarquía eclesiástica. Teología mistica. Cartas varias, Biblioteca de Autores Cristianos: Madrid.

${ }^{39}$ García Trabazo, José Virgilio (2002). Textos religiosos hititas. Mitos, plegarias y rituales. Colección: Biblioteca de Ciencias Bíblicas y Orientales número 6. Edición bilingüe crítica. Madrid.

${ }^{40}$ Hemos señalado algunos ejemplos, pueden añadirse el de Gilgamesh, Orfeo, la presencia en la Metamorfosis de Apuleyo en, El Libro de los Muertos en Egipto, hasta el Fragmento 17 de Safo.

${ }^{41}$ Sobre la Encarnación del Verbo.54.3. 
estaciones, por la marca de las cosechas? ¿"Dios se arrepintió de haber creado el mundo» ${ }^{42}$, como se lee en la Biblia y Cristo lo restaura? ${ }^{43}$ Todas las interpretaciones son confluyentes en una y única significación última: en el mundo hubo un desorden y una apetencia de restauración por obra de la Deidad.

El problema filológico, que tantas dificultades tiene para darnos a conocer qué es la Deidad, radica en que el método que usamos es racionalista, acuńado por una cultura de la mundanidad, y la Deidad pertenece al mundo de la sacralidad, reclama otra semántica y método, "lo que es tenido por sabiduría por los hombres, es estulticia para Dios" "44, dice San Pablo; aquí se encuentra la raíz del "Deus abscónditus" "5: los esfuerzos humanos por dar a la "caza alcance", como dice San Juan de la Cruz, fracasan, se trata de otro orden de conocimiento que la ciencia humana -respetable- puede acercarse, pero no alcanzar. Ricoeur en este sentido habla de "dar muerte a los idolos para rescatar los simbolos", lo que significa: negar la vía conceptual para acceder a la Deidad, a la que sí nos acercan los símbolos. Este ensayo que aquí redactamos, tiene precisamente la estructura del vuelo del águila caudal que gira y gira en acercamientos de círculos concéntricos hacia la presa, pero, sin que podamos lanzarnos raudos y seguros sobre la caza que avizoramos. Digamos, finalmente, que el mundo indoeuropeo, al que tantas veces nos estamos refiriendo, era ajeno a todo este racionalismo, materialismo y agnosticismo, existía en ellos una firme creencia en la existencia del más allá, y todo método debe adecuarse al objeto investigado. El principio de que a la verdad se llega solo por vía racional, hace muchos años que está descartado.

\section{3.- La Deidad se manifiesta}

La Deidad, no obstante sus ocultamientos, pues es Sacra (secreta), pide textos sagrados donde hacerse presente en forma privilegiada (Biblia, Vedas, Teogonía ${ }^{46}$

${ }^{42}$ Génesis 6.6.

${ }^{43}$ Para Romina Della Casa se trata de un hecho político, la restauración de un reino perdido in illo tempore. Véase: Una lectura simbólica de la permanencialtraslado de las divinidades de Hatti. En DavarLogos 9.2 (2010). Universidad Católica de Buenos Aires.

${ }^{44}$ San Pablo. Carta a los Filipenses. 3, 7-8.

${ }^{45}$ Sin olvidar que los estudios indoeuropeos hititas, se encuentra cada día con más sorpresas; tenemos al respecto más preguntas que respuestas. La lengua del Valle del Indus -cercano a India, Persia, Irak- está sin descifrar; y piensan algunos investigadores que puede ser el eslabón perdido para entender muchas interrogantes que hoy tenemos.

${ }^{46}$ West, Martin Litchfield (1966) (en griego - inglés). Hesiod Theogony. Londres: Oxford University Press. Hoy por hoy es la mejor traducción de la Teogonía, a pesar de la resistencia de muchos filólogos ingleses, que consideran no ser Hesíodo tan importante. 
hesiódica, Enuma Elish, Proclamación de Anita para los hititas etc.); se manifiesta además en imágenes (Siu para los hititas), templos (de Jerusalén para los hebreos, dham para los vedas), lugares geográficos (monte Fuji para los japoneses), sacramentos (para los católicos) o personas que por su heroísmo fueron elevados a dioses. Sobre este último concepto, señalemos que para Plutarco, fue Lisandro (m. 394 a. C.) el primer hombre elevado a categoría de dios. El culto a los héroes fue habitual en Grecia. Entre los latinos, leemos en Plinio: Las formas de dar las debidas gracias a los hombres del gran desierto, la más consagrada es el inscribirlos como dioses"; ¿’habrá que recordar que Cicerón dedicó un templo a su hija Tulia? ${ }^{47}$. Por cierto, el paganismo pre-cristiano culminó en el culto a Augusto. Si nos referimos al budismo, allí, el jainismo, que es una de sus ramas, existe también un culto a hombres divinizados. El Génesis al hablar de la creación de Adán dice que fue hecho a imagen (selem) y semejanza (demuth) de Dios ¿̇de qué modo la Deidad se hace presente aquí? Santo Tomás dirá que por analogía, no por ley de identidad; pero no siempre se ha entendido así en todas las religiones. La Deidad, en el orden del hombre, ha ido alejándose cada vez más de su manifestación exterior para interiorizarse: para hacerse un Dios de la fe. La raíz de ello se encuentra ya en el hinduismo. Si tenemos que elegir entre las religiones indoeuropeas una que se aproxime más a la judeo-cristiana, es la hinduista. Hay en ellas una depuración que va desde lo cosmológico, la magia y el panteísmo hacia una concepción de Deidad entendida como espiritual e interior, donde los conceptos de inmortalidad y salvación no son ajenos, "swargakamo juhuyat" ("se sacrifica para obtener el cielo"), incluso el concepto de gracia está recogido en la palabra "prasada", y la magia está en ellos superada, como confirman sus oraciones, todas ellas en optativo: ("Que consiga (paz, cosechas, ganados etc.) gracias al sacrificio).

Una de las formas de manifestación de la Deidad es a través de su palabra, depositada en sus hagiógrafos. Los hebreos y cristianos los llaman Escritores Sagrados; los vedas, Sabios; Hesíodo fue elegido entre los griegos por las Musas, entre los hititas los Escribas. La razón de la elección de los hagiógrafos es que

${ }^{47}$ Cicerón. Ep. Ad. Att., XII).

${ }^{48}$ No es de este estudio hacer una comparación entre cristianismo e hinduismo, hay estudios a este respecto. Solo recordemos que el mundo, en el hinduismo, apareció después que el dios fue sacrificado y sus restos arrojados dieron lugar precisamente al mundo ( $R g$-Veda: 10-90); salvando lo que hay que salvar, Cristo, sacrificado en la cruz, genera también el "Cristo cósmico"; porque Cristo murió y resucitó, una tensión se incorporó al mundo que lo empuja a "un cielo nuevo y una tierra nueva" (Apoc: 21:1-5); Teilhard de Chardin, por otros caminos antropológicos, llegará a lo mismo. 
la palabra de la Deidad no puede quedar a merced de la palabra limitada de cualquier hombre; los hombres hablan de la verdad, la Deidad habla la Verdad, y ésta debe ser transmitida mediante "inspiración" a ciertos hombres "divinamente elegidos" capaces de nombrar la Deidad en forma singularizada, con determinativo $D I N G I R$, y si en el mundo judeo-cristiano se habla de revelación, el Veda recibe el mismo nombre, Struti (revelación).

\section{4.- La Deidad vive en un tiempo Kairológico}

La Deidad es "deivos" y los hombres la escuchan desde su tiempo cronológico, ellos son "thonion", terrenales. Esta es una de las causas del misterio religioso o reserva a la comunicabilidad de la Deidad, además del "splendor divinitatis" del que ya hablamos. Sin embargo, esto necesita una precisión, pues existen dioses inmortales y dioses eternos, que no es lo mismo. Leemos en Safo: "Cuando eros (el amor) se mezclara con el caos en el oscuro tártaro, cuando el caos fue cubierto (sexualmente) por eros, apareció la primera generación de inmortales". Aquí eros es eterno y los dioses, innmortales. Lo eterno existe antes y después, lo inmortal -en este caso- después de ser creados. Eros pertenece al tiempo kairológico, en el caso de los inmortales participan del tiempo kronos pues fueron creados, pero ingresaron después al tiempo celeste. La situación de Cupido y Psiqué es similar: hay noche cuando Cupido y Psiqué consumaron su amor, pero este tiempo cronológico es abolido para que Apuleyo -que relata el mito- nos diga: sus padres envejecían, la noticia llegó a muchas partes.

Pero ¿quién es Eros? Una superdeidad? Como en el caso del Caos, un elemento lógico: Si aparecen los inmortales hay que justificar un principio, así lo hace Hesíodo: Eros existe antes de Gaya y Urano, a quienes une, para generar la creación.

\section{5.- El lenguaje con que se expresa la Deidad, son los símbolos}

¿Cómo hablar de lo inconmensurable con palabras mensurables? ${ }^{49}$ Los hagiógrafos (hebreos) los sabios (vedas) se expresan de la Deidad en términos de símbolos o en un lenguaje críptico y casi siempre en estilo de espiral o manierista, rodeo de palabras, tal como observamos en el "Himno de la creación" 50 , texto cosmogónico veda; la estructura de la obra de Hesíodo es similar, es de naveta de telar, va y vuelve, avanza y retrocede, una estructura que algunos

\footnotetext{
${ }^{49}$ Freitas, A. J. G. (2012). The language of the gods: Cosmogonic verbsand words. Talk delivered in the Research Seminar of the Department of Classics, Ohio State University.

${ }^{50}$ Rig Veda X.129.
} 
llaman espiraloide; por cierto en la bella narración hitita del mito de "El dios desaparecido", aquí se reiteran los verbos y sinónimos para indicarnos los efectos paralizantes que ocurren en la naturaleza tras la desaparición de su dios; como en el caso de citado himno védico, estamos tentados a decir ¿por qué todo eso no lo dice con un término genérico?

Sobre los símbolos y su apelación a lo sagrado, pueden verse los estudios de Paul Ricoeur y Mircea Eliade. Símbolo (sym-balein) significa lanzar a la vez dos partes de una moneda que forman una alianza, una parte es la que poseemos, la otra -en este caso la Deidad- está en otra parte. El símbolo busca encajar ambas partes, hacer un puente para la comprensión, esto no es fácil, demanda un esfuerzo, casi diríamos una purgación, sin la cual nadie se puede acercar a la Deidad. Al símbolo anima una escisión que hay que sufrir penitencialmente en favor de una revelación de la Deidad.

El símbolo, como estudia Eugenio Trías ${ }^{51}$, necesita un escenario, un ambiente sacro, un silencio para que se manifieste lo simbolizado. ¿Cuáles fueron estos escenarios en las distintas religiones? El más recurrente es el templo, también la meditación, el silencio y lugares apartados -el yermo, cuyo primer lugar fue aquél en el que Dios se apareció a Moisés y le dijo; "descálzate, porque la tierra que pisas santa es ${ }^{\prime 52}$; t también la Deidad se manifiesta en la palabra decantada de los poetas: Fray Luis de León dice que la poesía, "sin duda la inspiró Dios en los ánimos de los hombres, para con el movimiento y espiritu de ella levantarlos al cielo, de donde ella procede; porque poesía no es sino una comunicación del aliento celestial y divino; y asi en los profetas casi todos, asi los que fueron verdaderamente movidos por Dios, como los que incitados por otras causas sobrehumanas hablaron, el mismo espiritu que los despertaba y levantaba a ver lo que otros hombres no veian, les ordenaba y componía y como metrificaba en la boca las palabras, con número y consonancia debida, para que hablasen por más subida manera que las otras gentes hablaron, y para que el estilo del decir se asemejase al sentir, y las palabras y las cosas fueran conformes"53; algo que el Rig-Veda, cuyo nombre significa El conocimiento alabable, nos dice: "Los poetas son camaradas de los dioses, poseedores de la verdad; $y$ los poetas son tan antiguos como los dioses, son los padres que fundaron la luz e hicieron desaparecer las tinieblas con verdaderas oraciones ${ }^{54}$.

${ }^{51}$ Eugenio Trías (1997), en "Pensar la Religión", Seminario de Capri bajo la dirección de G. Vattimo y J. Derrida; Págs. 133/152, ediciones de la Flor, Buenos Aires, Argentina.

52 ÉxODO.3.

${ }^{53}$ Fray Luis de León. Obras Completas Castellanas. "De los nombres de Cristo", págs. 253-254. BAC. Ed. preparada por el P.Félix García.

${ }^{54}$ Rig-Veda. $\mathrm{N}^{\circ} 7.764$. 
El símbolo hace que la Deidad acontezca, aunque siempre con los vislumbres que la palabra, la imagen, el templo u otras formas simbólicas en sus limitaciones materiales, permiten que la Deidad nos mire. No sucede así con el culto a Varuna o Indra, que si se les ofrece una copa con un contenido, ésta se deifica, en términos cristianos se consagra.

\section{6.- Algunos símbolos de la Deidad}

La Deidad se expresa con manifestaciones de su presencia y con características distintas, las más frecuentes: Una imagen, una silla, un cerro, un templo, un palacio, un texto etc. Leemos en la Enciclopedia Católica: "Elfuego, como elpoder calentador, nutritivo, consumidor y destructor fue tempranamente venerado como una deidad separada; de ahi, las vírgenes vestales de Roma, el Agni védico, los adoradores del fuego del mazdeismo, y el fuego sagrado del sintoísmo. Asi también, la humedad o el agua ${ }^{55}$, no sólo en general, sino en sus formas concretas, por ejemplo, mar, lago, río, fuente, nube, y asi fue que tuvieron una cuarta deidad elemental. En el Oriente la astrolatría o sabeísmo---es decir, el culto a las estrellas que iluminan la tierra---desarrolló sobre todo el culto al sol. Donde el suelo y la vegetación eran ricos, la tierra era considerada como una madre que amamanta, y surgió la geolatría en muchas formas. En los himnos védicos podemos rastrear la transición de los fenómenos naturales a las deidades naturales---por ejemplo, Agni, o sea, fuego; Varuna, o sea, el cielo; Indra, o sea, las nubes de lluvia---pero incluso entonces surgen dudas, y los escritores poéticos se preguntan si, después de todo, hay cosas tales como los devas. En Homero y Hesíodo las fuerzas de la naturaleza se conciben como personas---por ejemplo, Urano (el cielo); Nyx (noche); Hipnos (sueño); Oneiros (sueño); Oceanos (océano)---la respuesta de Aquiles al rio Escamandro "en forma humana, confesó ante sus ojos" 56 y su oración a los vientos Bóreas y Céfiro, que avivaran las llamas de la pira funeraria de Patroclo ${ }^{57}$ La observación del hecho de que en la naturaleza se combinas dos energías---una activo y generativo, la otra pasiva y femenina---, llevó al hombre a asociar cielo y tierra, sol y luna, dia y noche, como deidades primigenias y maternales que cooperan en la producción del ser. De ahi la distinción de divinidades masculinas---por ejemplo, el cielo, el éter, el sol---y las divinidades femeninas---por ejemplo, la tierra, el aire, la luna. De esto hay sólo un paso a la deificación del principio generador y el culto al phallus'58.

55 De Freitas, Antonio.(2012). ":Agua, elemento importado en las cosmogonías griegas?". Ponencia en el VI Coloquio AGON. Universidad de La Plata.

${ }^{56}$ Iliada, XXI.

${ }^{57}$ Ilíada, XXII.

${ }^{58}$ Driscoll, John T. "Deity." The Catholic Encyclopedia. Vol. 4. NewYork: Robert Appleton Company, 1908. 
Y con respecto a la manifestación de la Deidad en un palacio, recordemos el Libro $\mathrm{V}$ de El asno de oro de Apuleyo en el que el palacio, se dice, solo podía haberlo hecho "un artista maravilloso, mejor dicho, un semidiós, o exactamente un dios auténtico... si algo falta alli, es porque no existe ${ }^{\text {"59. }}$. Lo que nos plantea, con respecto a la noción de Deidad, si este concepto es solo aplicable a "dioses auténticos” y ¿̨uáles son éstos?

La noción de la Deidad como dueña de la naturaleza la encontramos en numerosos textos indoeuropeos: en el Himno védico sobre la creación -la Deidad controla todas las leyes-; Cronos -padre de Zeus- es dios de las cosechas en Grecia y entre los hititas, en "El mito del dios desaparecido" éste, encolerizado, produce un cataclismo cósmico, las leyes de la naturaleza se alteran y la fecundidad muere pero no sus huellas' ${ }^{\prime}$. En definitiva, debemos decir con Ortega: "No hay cosa en el orbe por donde no pase algún nervio divino: la dificultad estriba en llegar hasta él $y$ hacer que se contraiga'r1.

\section{7.- La Deidad es trascendente}

Lo que implica omnisciencia, eternidad, infinitud, condición de ser necesario, ser primigenio, existencia en una dimensión kairológica o tener vida "sub specie aeternitatis". Este concepto se aviene con los "dii immortales" de los romanos, los "theoi athanatoi" de los griegos, los Amartya de los hindúes, los dioses inmortales de Babilonia, y las deidades de Egipto, reyes sobre la muerte y los muertos. Eternidad ¿supone que la Deidad existió desde la eternidad con la creación o fue antes de la creación? Las cosmogonías disienten al respecto, en algunas es antes la cosmogonía y después la teogonía, en otras, como la bíblica, Dios es el origen, crea el mundo de la nada, la palabra "bará" (crear) está reservada para Dios. Para los judíos, Dios era único, solo y eterno, para los filósofos griegos los dioses, la teogonía, aparece después del cosmogónico “caos"62. En la cosmogonía babilónica del Enuma Elish, como en la bíblica, se parte de la nada, lo inicial es lo no nombrado, después Absu y Tiamat engendrarán los demás dioses; ciertamente, aunque en el verso 5, se lee "A MES sunu istenis ihquuma", "mezclaron sus aguas" a partir de ahí aparecen los dioses" ${ }^{63}$ : "Cuando en lo alto, el Cielo no estaba nombrado, y la Tierra, abajo, aún

\footnotetext{
${ }^{59}$ Apuleyo. (2001) El asno de oro. L.V. 4-5 y 2.2. Madrid. Gredos.

${ }^{60}$ García T. José Virgilio. Textos hititas. Madrid. Ed. Trotta.

${ }^{61}$ Ortega y Gasset, J. (1963), Obras Completas. Revista de Occidente, Madrid. Vol.II, pág.322.

${ }^{62}$ Freitas, A. J. G. (2010). A reflection on Hesiod's Cosmos. Thebeginning of Greek Speculation, PhD Thesis, Universidade da Madeira. Muchas de las ideas aquí expuestas corresponden al Seminario sobre Mitos Indoeuropeos, seguido en Santiago de Chile bajo la dirección del señor Freitas.

${ }^{63}$ Freitas, A.J.G. "¿Agua, elemento importado en las cosmogonías griegas?", ponencia citada.
} 
no tenía razón: El primigenio Absî, que los engendró y, Tiamat, la madre de ambos, sus aguas mezclaron. (Cuando) los campos no habian sido creados, y los pantanos no eran posibles de vislumbrar. Cuando ninguno de los dioses habia sido llamado a existir, al no poseer (todavía) nombre, y los destinos (aún) no estaban escritos" ${ }^{64}$. También el "Himno védico de la creación" parte de la nada, se lee: "No fue ni el noexistente, ni el existente ${ }^{765}$. En todas ellas, la Deidad tiene el don de ser primigenia a otros dioses (Gaia, griegos) o seres (Dios bíblico). En todo caso, la pregunta sigue latente ¿y quién creó los elementos de la Cosmogonía cuando ésta precede a la Teogonía, sino una Deidad? La respuesta también puede ser otra: antes de la Teogonía no existe nada y si se habla de ésta es como hablamos en Matemáticas del cero antes de nombrar el uno, un elemento vacío, un concepto lógico que nos permite empezar ${ }^{66}$. El hinduismo tiende a sustraerse de este cosmologismo, pues mientras Agni y Surya se refieren al fuego y al sol -con una referencia cósmica- son dioses menores, y Indra, Varuna, Mitra, Rudra, Visnú y Siva, los grandes dioses, son ajenos a todo cosmologismo ${ }^{67}$.

Pero la Deidad encierra otro rasgo: mostrar la otredad, se lee en Ferekides (fragmento 14): "Gaia, la primera que dio origen a aquel que es igual a sí mismo" 68. La otredad se define a partir de uno, decir lo que no soy yo. Urano es ya diferente a Gaia, es otredad, y a partir de ahí comienza la Teogonía griega, los dioses, y se completa el cosmos. Gaia reconoce al otro socialmente. En el "Himno védico sobre la creación” se atisba también este carácter de otredad propio de la Deidad, se lee: "El uno respiró sin aire", éste uno no es aún persona y debemos distinguir entre uno, el uno y la unidad; sin embargo, lo Uno-Deidad-lo que existe en sí y para sí, no necesita la otredad para existir, la otredad siempre relativiza. La Deidad no es contingente, lo contingente es lo que necesita de lo otro, de la otredad para existir.

Un rasgo más de esta Deidad trascendente es el omniconocimiento: El Dios de la Biblia conoce todo (Salmo 139), "Zeus es el de amplia mirada" (Homero), "El lo sabe todo" (Himno védico). Todas las Deidades primigenias son omniscientes y proféticas, como lo fue la Diosa Primigenia del mito hitita del "Dios desaparecido",

64 “El Enuma Elish. El poema de la Creación”. Traducción de Luis Astey V. 1989.

${ }^{65}$ Rig Veda. X .128.

${ }^{66}$ López Ruiz, Carolina, (2010). When the Gods Were Born: Greek Cosmogonies and the Near East, Harvard University Press. Véase Antonio de Freitas, texto citado, Comunicación en el VI Congreso AGON. Universidad de La Plata, 2012.

${ }^{67}$ Las ideas de Max Müller (1823-1900) y James Frazer (1854-1941), sobre el hinduismo, están hoy obsoletas.

${ }^{68}$ Ferekides (fragmento 14). 
ella sabe dónde está, después que otros muchos lo buscaron sin efecto, y manda a una abeja que al final lo despierta, y se produce la "reintegratio mundi". Los dioses primigenios no intervienen directamente.

La cualidad trascendente de la Deidad generó siempre una tensión con lo inmanente del hombre hasta la llegada del cristianismo, religión en la que " $E l$ Verbo se hizo carne" ${ }^{69}$, ahora Dios es Creador del cielo y de la tierra, de lo visible y de lo invisible (Concilio de Nicea). Santo Tomás dedicará un largo espacio de su Summa Theológica a dilucidar este problema, central en el cristianismo. Pero no fue así antes del cristianismo ${ }^{70}$, existían aproximaciones de los dioses hacia los hombres, como si quisiesen compartir con ellos, es el caso del palacio de Cupido en el Libro V de El asno de oro de Apuleyo donde se lee: "Parece muy verosímil que el gran Júpiter se haya construido este paraíso como palacio en la tierra para vivir con los hombres" ${ }^{71}$, en otros casos, el rey tenía una función cósmica, era rey, Sumo Sacerdote o Póntifex, pero no era la Deidad. El rey hitita, en este sentido, era mediador con la Deidad, no la Deidad; su escudo tiene tres cuarteles, que significan las tres partes del templo: una, para el público general; la segunda, solo para los fieles y la tercera, para el Sumo Sacerdote, el Sancta Sanctorum en términos hebreos o Sagrario en el templo católico, espacio sagrado que el rey de Micenas, por influencia hitita, reservaba también para sí. Dígase lo mismo sobre la aproximación en el mundo védico de los dioses a los hombres: las dos encarnaciones mayores del dios Visnu -Rama, primero, y luego Krysna- son para poner orden religioso, pero después vuelven a su primitiva condición divina en el cielo (vaikuntha), no obstante el que en el culto diario antes de la salida del sol y cuando se pone (surya-namaskara) la invocación implica también el mundo creado o lo cósmico: “Que el sol se levante para que nosotros vivamos!”, se ora en la mañana, y en la tarde: «QQue regrese el sol tras su viaje nocturno!”. En el sánscrito el mundo está fragmentado (profanidad), pero está llamado a una "reintegratio", (samskara), que es descubrir la primitiva unidad con que los dioses liberaron al mundo del caos.

Las múltiples vinculaciones que hemos hecho entre aquella cultura del Oriente Medio y Grecia, es lo que llevó a decir -tal vez exageradamente- a M. L. West: "Grecia es parte de Asia; La literatura griega es la literatura de Oriente

\footnotetext{
${ }^{69}$ Prólogo. Evangelio de San Juan.

${ }^{70}$ Suma Teológica. Cuestión 44 a 47. Trad. José María Artola Barrenechea. Madrid. BAC.

${ }^{71}$ Apuleyo. o.cit. L.V. 7.
} 
Próximo... ". Debemos librarnos tanto del helenocentrismo, tan afecto a ingleses y alemanes, como del helenismo.

\section{8.- La Deidad como Dios interior}

Resulta extraño que en las religiones más primitivas se pueda hablar de una Deidad, que se manifiesta en lo interior del hombre: un Dios de la fe se diría en términos cristianos. No obstante ello, toda Deidad opera una conmoción en el creyente. En el texto védico Bhagavad-Gita, texto de gran respeto, Krsna encarnación del dios supremo Visnu, enseña al príncipe Arjuna la intensa devoción interior (bhakti), nada podrá ser grato a la Deidad sin un sacrificio interior: el corazón es un fuego donde debe depositarse la oración para que sea acepta. Los monjes apartados de la vida social (sadhu) cumplen de modo particular, en la soledad, la meditación y el silencio, esta comunicación con la Deidad, la hacen a través del fuego interior (Agni).

¿Agni es un mediador o una presencia de la Deidad? Suele identificarse con la omnisciencia divina, la conciencia religiosa vigilante que habita en lo más íntimo del ser, intuición intelectual, luz espiritual, que en diversos textos se califica de modo distinto Lo que no cabe duda es que hay en él una participación interior de la Deidad.

Este sentido interior de lo religioso alcanzará también a las imágenes de los dioses en el mundo védico, a ellas no se les da culto por ellas mismas, si no por lo que representan. No hay idolatría en el hinduismo como tampoco en el catolicismo. La acción de los artistas entre los indues reclama, antes de iniciar su obra artística religiosa, esta transformación interior: "La excelencia de la forma se hace clara en el acto mismo de la identificación" (dhyana) ${ }^{72}$; algo que coincide con el consejo de Dionisio Areopagita cuando aconsejaba: nadie debe enseñar algo religioso, que no lo haya previamente experimentado: “...quienquiera que pretenda abusivamente enseñar la santidad antes de practicarla él mismo de manera constante, un tal es impio y totalmente extranjero a nuestras santas instituciones.... asi debe evitarse siempre la audacia de mostrar a otros las vias de Dios si no ha uno mismo logrado una deificación perfecta y durable, si la inspiración y la elección divinas no nos han llamado a la función de jefes" 73 .

\footnotetext{
${ }^{72}$ VSU III, 14.

${ }^{73}$ O.cit. pág. 280.
} 


\section{La Deidad contra el Mal: El Dragón}

Propio de la Deidad es establecer su reino, una reintegración del mundo -como hemos señalado- venciendo el mal; este mal está simbolizado en el Dragón. El mito de la Deidad contra el dragón recorre toda la cultura indoeuropea, desde la época más remota hasta la obra de Kiko Arguelles “Una gran señal”, música épica, de lucha contra el dragón del Apocalipsis, como señala la letra de su música.

El dragón, como Anti-Deidad, tiene en el mundo indoeuropeo una connotación negativa ${ }^{74}$, lo que no sucede en la China, que simboliza positivamente al Emperador, el señor de los cuatro elementos, pues el dragón: vuela (aire), vive en los ríos y pantanos (agua), se arrastra (tierra) y lanza fuego por su boca. Existe una primera muestra de esta Anti-Deidad indoeuropea en el Museo de la Civilización de Anatolia, en Ankara (Turquía): la Deidad ${ }^{75}$, el Dios de las Tormentas, mata al dragón Ulliyanka. Recuérdese la etimología: Ulliyanka (hitita)>aji (védico)>anguila (latín), que sugiere serpiente o dragón. Prescindimos de la doble versión sobre este mito y sus variantes. Lo que sí nos llama la atención, para definir mejor el concepto de Deidad, es que El Dios de las Tormentas, pese a estar señalado con el determinativo Dingir, no es, al menos inicialmente, superior a la Anti-Deidad o el dragón, pues éste, Ulliyanka, le saca los ojos y el corazón, y El Dios de las Tormentas ha de pedir ayuda a un hombre, un sabio, que, habiendo restituido el robo anatómico al Dios de las Tormentas, logra al final vencer al dragón. En el caso de la religión védica, Indra y otros dioses piden al sabio les permita usar la espada para matar al dragón, aquí los dioses están sometidos a la sabiduría, la sabiduría es más importante que los dioses, es cualidad esencial de la Deidad; esta sabiduría, cualidad de la Deidad está depositada solo en los dioses primigenios. El Himno de la Creación, himno védico, canta precisamente a esta sabiduría, no en vano Veda significa El conocimiento laudable. La raíz védica (weid) se tranferirá al griego eidos (el saber o conocer interior o sabiduría), en latín video y que en inglés dará: wisdom (sabiduría), wise (sabio) y wizard (mago).

El Festival de Teatro, que en el mundo hitita representaba este mito en forma mucho más ampliada, concluía con el Rey que al final, conseguía el control del mundo. La lucha entre el Bien (Deidad) y el Mal (Anti-Deidad) termina siempre

\footnotetext{
${ }^{74}$ Pueden verse Textos religiosos hititas, recogidos, estudiados, y puntualmente editados por José Virgilio García Trabazo (Madrid. Edit. Trotta, 2002).

${ }^{75}$ Se expresa con Dingir DIm.
} 
en la mitología indoeuropea con una victoria satisfatoria en virtud del triunfo de la sabiduría.

El traspaso del mito del dragón a occidente tuvo algunos hitos significativos, aquí un pequeño recuento:

-Apolo mata a la serpiente Pitón ${ }^{76}$.

-Un dragón cuida el Vellocino de Oro, dragón que Medea mata con una pócima ${ }^{77}$.

-Orfeo adormece con su música al dragón ${ }^{78}$.

- Cadmo vence al dragón para fundar Tebas ${ }^{79}$.

-Hércules frente a la Hidra ${ }^{80}$.

Las vinculaciones del mito del dragón con la Biblia son también manifiestas: el demonio, como el mal disfrazado de serpiente en el Génesis. En el Apocalipsis ${ }^{81}$, el dragón es el Demonio que hay que destruir. Una idea que pasa después al occidente cristiano como el Mal, la Idolatría o la religión pagana que hay que hacer desaparecer; en la Edad Media, San Jorge vence al dragón y es el patrono de Inglaterra, pues allí el monje San Agustín encontró el dragón de creencias que había que vencer. El mismo significado se encuentra en las leyendas del Santo Grial, novelas de caballería y Beowlf. La cristianización de los pueblos nórdicos fue tardía y por eso el imaginario del dragón aparece en su literatura más tarde.

En el mundo inicial indoeuropeo y hebreo el dragón era el Mal, entre los hebreos, el pecado, en el occidente cristianizado, como hemos señalado, el mal de otras creencias que hay que desarraigar. Tal vez sea San Jorge quien en esto representa el imaginario religioso más rico: San Jorge sería el creyente representativo del "miles Christi", pues su caballo blanco sería la Iglesia y el dragón, el paganismo, la idolatría, la tentación y Satanás. Baste decir que en Francia existen 81 localidades con el nombre de San Jorge.

El mito del dragón es una de las marcas más persistentes de la civilización oriental y occidental indoeuropeas, pero por ser la Anti-Deidad.

\footnotetext{
${ }^{76}$ Himno a Apolo, 363 y ss.

${ }^{77}$ Eurípides. Medea, $465-519$.

${ }^{78}$ Bernabé, Alberto y Francesc Casadesú. (2008). Orfeo y la tradición órfica. Madrid. Akal.

${ }^{79}$ Nono de Panópolis, Dionisíacas 4, 355 ss.

${ }^{80}$ Numerosas fuentes: Séneca Hercules furens; Higinio. Fabulae. Pausanias Historia de Grecia 2.37.4 etc.

${ }^{81}$ Apocalipsis: $12.3 ; 12.9 ; 13.14-15 ; 13.18$ etc.
} 


\section{La Deidad y Justicia}

Este excurso va tener como telón de fondo, la Teogonía de Hesíodo (vs.346, 348, 386 y 395). Propio de la Deidad es la justicia divina, significada por Themis y no por Diké, pues ésta es la justicia humana. Themis, hija de Zeus, es la justicia como Deidad, la Deidad es justa y hace justicia cósmica. Themis es quien instaura en el cosmos la justicia de su padre Zeus.

La theomaquia de Zeus contra Cronos tuvo como fin crear un nuevo cosmos: dar a cada uno lo suyo, que es la justicia, es la Moira o establecido. Esta es la razón por la que es deber de los reyes promover y mantener el buen orden, es su parte o Moira, no hacerlo es instalar el antiguo caos “crónico” (de Cronos), Respetar la Moira de cada uno es garante de justicia, de orden y armonía, y la armonía, orden y justicia son cualidades de la Deidad, en el caso griego, de Zeus. Si Zeus se levantó contra Cronos, fue porque Cronos no respetó la Moira, la parte dada a cada dios, no respetó la justicia trascendente, divinal o de la Deidad. Cronos robó a los dioses, lo que les correspondía, que era su Moira.

Hesíodo nos lleva a la conclusión de que la Deidad es lo justo transcendente o la justicia en sí. La justicia en sí no puede corromperse -según Hesíodocomo Zeus no puede corromperse. La Idea en Platón, en otra analogía, no puede corromperse, pues pertenece al estrato más alto, a la Deidad. Este pensamiento estaba ya en los Vedas, no es extraño haya llegado a Hesíodo, pues su familia procedía de Anatolia, región tan vinculada a los orígenes indoeuropeos y la India. El caso de Platón es más cuestionable, aunque, si la lingüística indoeuropea mantuvo un continuum con el idioma griego, ahí estaban ya bajo las palabras las ideas de lo inmutable que, tal vez Platón en forma inconscientemente desarrolló ${ }^{82}$.

A Hesíodo siguen en esta conceptuación de la justicia o Moira: Cálinos (650 a.C.), Baquílides (520 a. C.), Esquilo (525 a.C.), que consideran existe una sola Moira, una sola justicia, como existe una sola Deidad. No sigue estas ideas Anaximandro, niega a los dioses para instalar sola la justicia cósmica. Anaximandro (610-545), con respecto a Hesíodo, es un retroceso. Para este filósofo griego, el cosmos se hace autónomo y será la Diké humana la que debe repartir la justicia, la Moira es una idea humana y, por tanto, no existe Deidad o el hombre se ha hecho Deidad.

${ }^{82}$ Existe un consenso entre los indoeuropeístas, y es que mientras no se descifre el lenguaje del Valle del Indo, nos faltará el "eslabón perdido", para entender muchas cosas de la cultura indoeuropea. 
En conclusión. Las vinculaciones de Justicia $>$ Moira $>$ Zeus $>$ Deidad están muy presentes en Hesíodo, como ha demostrado José Antonio Goncalves Freitas en sus investigaciones al respecto, ideas que aquí seguimos: Toda la Teogonía, todo el origen y desarrollo del mundo en Hesíodo, estaba dirigido a la aparición de Zeus. La primera generación de dioses, procedentes de Gaia y Urano, conducen a Zeus. Existía una profecía según la cual el hijo de Cronos tomaría el reino y se instalaría la justicia, la Moira, léase Deidad. Serán Themis y Afrodita quienes extenderán luego en el mundo esta justicia. Zeus macula a Cronos para que no fecunde más la injusticia, la Anti-Moira, y de la sangre de Cronos nacerá Afrodita, el amor, de la hybris surge ahora la sofrosine. La Moira ahora dará a cada uno lo suyo, que en esto consiste la justicia, el orden, la armonía y la paz con el amor ${ }^{83}$, dones de la Deidad. Cuando la justicia divina no se cumpla -dice Hesíodo- los lamentos de la Diké se escucharán en todo el mundo.

Pero ¿qué existe antes de Zeus y la Moira? ¿quién dicta la profecía que el Caos dará lugar a Gaia y Urano y después la Theomaquia contra la injusticia y que llegará después Zeus? Llegamos de nuevo al Deus absconditus. Lo físico no puede acceder a lo metafísico, puede preguntarse por él, pero no puede responder, toda vez que pertenece a otro orden. Como en el caso de la caverna de Platón, podemos ver sombras, pero no la luz plena de las Ideas. La Deidad calla, acaso por ello Homero canta al mundo de los dioses, pero no los explica, no hay en él sucesión, historia, lo que sí sucede con Hesíodo, cuyo mundo es móvil, fluido.

La idea de Deidad nos ha llevado nuevamente a la frontera de la Deidad: tema en que confluyen mitólogos y filósofos, ambos en una doble abertura: unos que consideran la Deidad como fundamento (Aristóteles, Santo Tomás, Suárez, Leibniz, por cierto los neo-tomistas) otros que prefieren hablar de una Deidad que es fundamento, pero sin demostración, "teología negativa” ( Dionisio el Areopagita, Eckhart, Tauler, Silesius, Cusa y, entre los más cercanos, Schelling); esta teología de la Deidad, como "abismo", (Heidegger), "mar sin fondo" (Eckhart), "el saber del no saber" (Nicolás de Cusa), es la misma de la que dan cuenta las distintas mitologías y hasta los poetas más desacralizados a la hora de entregarse a la metáfora voladora. Escribe Neruda:

\footnotetext{
${ }^{83}$ El tema del amor y la Deidad, es una ausencia en este ensayo, porque nos supera. En alguna ocasión, con más fuerzas y tiempo, lo intentaremos. Solo recordemos que la diosa caldea Ishtar, desdeñada por Izdubar-Nimrod, amenaza a la Deidad Anu, con destruir el mundo simplemente suspendiendo las leyes del amor.
} 


\author{
y yo mínimo ser \\ ebrio del gran vacio \\ constelado \\ a semejanza, a imagen \\ del misterio \\ me senti parte pura \\ del abismo \\ rodé con las estrellas \\ mi corazón se desató en lo viento ${ }^{84}$.
}

El tema es tesis fundamental de la filosofía de Trias; algunos hablan del "conocimiento silencioso de la Deidad" (Maharshi) ${ }^{85}$; Sartre se refería a ella como "el vértigo de la existencia"; para Juan de la Cruz, "La Deidad es el olvido en la plenitud" y Fray Luis de León, después de experimentarla, exclamará:

\title{
¡Oh, muerte, que das vida!
}

¡Oh, dulce olvido!

Durase en tu reposo, sin ser restituido

a este bajo y vil sentido ${ }^{86}$.

Pero prefiero concluir este excursus con la frase de Heidegger, voz en la que escuchamos la voz de todas las mitologías: "Los mortales habitan en cuanto esperan a los Divinos. Esperando, mantienen contrapuesto a ellos lo inesperado. Aguardan la señal de su llegada y no desconocen los indicios de su falta. No se hacen sus dioses y no practican el culto de idolos. En la desgracia" 87.

\section{1.- La Deidad, se revela en la persona}

Muchos acercamientos hemos hecho ya sobre este tema, pero será conveniente puntualizar. En Israel existía el culto del templo, comunitario, cuyo fin era la ayuda a la salvación personal; pero existía también un culto particularmente

${ }^{84}$ Neruda. Memorial de Isla Negra.

${ }^{85}$ Hay también un conocimiento cauteloso, es el de Ortega y Gasset y Heidegger, puede verse:"Acerca de la meditación en torno a lo divino en pensadores contemporáneos", de Jorge Acevedo Guerra, en Revista Chilena de Humanidades, Nº14 (Santiago de Chile, 1993). Número que recoge las ponencias del Encuentro de Reflexión sobre el Discurso Religioso (Facultad de Filosofía y Humanidades de la Universidad de Chile).

${ }^{86}$ Fray Luis de León, Oda a Salinas.

87 "Construir, habitar, pensar" en Ciencia y Técnica, trad.Francisco Soler. Edit. Universitaria, Santiago, 1993 ("Bauen Wohnen Denken", en Vorträge und Aufs̈̈tze.II, Neske, Pfullingen, 1967. 
personal, el de la liturgia penitencial, de acuerdo con el pecado personal, y la defensa también personal, cuando alguien se sentía injustamente acusado. Ambas situaciones, ponían a la Deidad en el centro del corazón de cada persona y no solo en el Santa Sanctorum. Dígase lo mismo del profetismo, los profetas se sienten personalmente elegidos por Dios, al margen muchas veces de la conducta religiosa oficial, tantas veces desviada. En Grecia y otros países indoeuropeos, esta función la cumplían los oráculos. Esto nos lleva a concluir desde ya que, a la hora de sistematizar experiencia religiosa personal y noción de Deidad resulta todo muy complejo, pues los discursos personales nunca son homogéneos y desde la subjetividad salta con mucha frecuencia lo poético y simbólico, otro gran tema de la Deidad como experiencia personal.

Los poemas más sentidos en la literatura religiosa, son aquellos nacidos no comunitariamente, si no de la propia situación personal, un ejemplo el Salmo 22(23) en la literatura hebrea, el lamento de Medea en Eurípides, la súplica a Varuna en el Himno Védico-124, por no recordar la Noche oscura del alma de San Juan de la Cruz o a Fray Luis de León en su Vida retirada. Fray Luis transforma el ejercicio retórico, escolar, del Beatus ille de Horacio en experiencia viva, perseguida y maltratada, en su famosa oda. Ha sido Ricoeur quien mejor ha explicado el trasfondo de la revelación personal de la Deidad a través de la poesía: La poesía, señala, no apunta a algo externamente referencial, no va a una referencia descriptiva, lo divino no se describe, apunta a algo fuera del texto a lo que nos lleva la metáfora poética, la poesía "da quépensar", porque supera el intramundo para llevarnos al extra-mundo, en cuyas fronteras -decimos nosotros- se encuentra la Deidad. En definitiva, la poesía es una revelación ontológica y en lo ontológico está Dios, lo que nos confirma aquello de Heidegger: "La casa del ser es la palabra y el poeta su guardián”, que, con otras palabras repite en otros muchos textos, así cuando habla de "la devoción del reflexionar"88. Precisamente reflexionar se deriva del latín re-flectus, acción de doblar, curvar, de aquí genuflexión, postura para el supremo pensar que es la meditación.

Lejos de nosotros el caer en un "iluminismo" deísta agnóstico: en el discurso poético no se traicionan los fundamentos del conocer, expresados en aquel "adequatio mentis cum re"; debemos distinguir entre "verdad adecuación" y "verdad-revelación". La metáfora no se desvanece en un mero "aludir" a algo,

${ }^{88}$ Heidegger (1987) De camino al habla. Barcelona, Serbal-Guitard, pág. 157. habla de "la devoción del pensar"; en Qué es metafísica. La Plata. U.N.L.P. 1964, pág.84, leemos "el poeta nombra lo sagrado". Lo mismo en La pregunta por la técnica. Córdoba, Multi- Editora, 1958, pág.79. 
"incitar" a algo, "sugerir" algo numinoso, toda metáfora regresa siempre al concepto, señala Ricoeur, pero no para definir algo, siempre para situar algo. La Deidad pide siempre ser situada. Los múltiples nombres con que se designa a la Deidad en la Biblia o a Alá en el Corán o los mil nombres dados a Visnú entre los vedas, -Vijaya Kumar escribió un libro sobre The thousand names of Vishnuno nos lleva a la selva del nominalismo escéptico, acusa, antes bien, la unidad y potencialidad de la Deidad.

\section{Conclusión}

La Deidad ha sido una preocupación permanente de todos los pueblos, pertenece a imaginario antropológico religioso. No obstante ello, el mundo indoeuropeo y también el semita, han logrado un acercamiento en la caracterización de la Deidad, cuyos rasgos esenciales hemos tratado de definir en este ensayo. Estos rasgos, en resumen, son: La comunicabilidad o el carácter de Pater, lo que conlleva el amor, que es fecundo (cosmogonía y teogonía) y la restauración del cosmos (mito del dios perdido); esta comunicabilidad, no se opone a la reserva, propia de la Deidad, pues ella goza de Unidad, es Luz que deslumbra más allá de otra luz, lo que hace que se presente al hombre como "Deus abcónditus", de ahí que se diga de la Deidad, ser inmortal, "theoi athanatoi", acto puro. La Deidad, en cuanto amor, rompe con su ser "a se" y se revela eligiendo a sabios, escribas o hagiógrafos, a quienes encarga cuidadosamente su revelación (Veda, Biblia, significan Revelación). Si de la Deidad se dice que es "deivos", pues vive en un tiempo kairológico, alejado de nosotros, no en nuestro tiempo cronológico o degradante, necesita esta re-velación, quitar el velo o desocultarse. Pero, los seres humanos que somos, "thonion", mundanos, tenemos nuestra propia “revelación”, pues la Deidad está escrita en el corazón del hombre, y podemos vislumbrarla a través de símbolos, siendo uno de los más eficaces la poesía: la metáfora nos lanza siempre a una significación "otra", que no es la humana. Finalmente, la Deidad a través de la palabra revelada o de la palabra metaforizada, es para el hombre, se hace presente en el interior del ser humano: "Dios es más interior que yo mismo" (San Agustín), los vedas hablan del bhakti.

Pero, no se puede definir la Deidad sin su negativo la Anti-Deidad, que es el Mal, el Pecado, la Injusticia, cuyo símbolo es La Bestia, El Dragón, pero que no triunfa, pues de la Deidad es establecer un reino de justicia (Los dioses perdidos vuelven, Zeus restablece la justicia arrebatada por Cronos y la Bestia apocalíptica, es vencida). 


\section{Referencias bibliográficas}

Acevedo Guerra, J. (1993) "Acerca de la meditación en torno a lo divino en pensadores contemporáneos", en Revista Chilena de Humanidades, N¹4 (Santiago de Chile, 1993). Número que recoge las ponencias del Encuentro de Reflexión sobre el Discurso Religioso (Facultad de Filosofía y Humanidades de la Universidad de Chile).

Apuleyo (2001), El asno de oro. L.V. 4-5 y 2.2. Madrid. Gredos. Cicerón. Ep. Ad. Att., XII).

Bermejo Barrera, J.C. (1994), Introducción a la Sociología del Mito. Madrid. Akal.

Bernabé, A. (2003), Hieros-Logos. Poesía órfica sobre los dioses, el alma y el más allá. Akal Clásica.

Bernabé, A. y Francesc Casadesú (2008). Orfeo y la tradición órfica. Madrid. Akal.

Boyer, R. (1995). "El Mundo Indoeuropeo" en Tratado de antropología de lo sagrado (2). El hombre indoeuropeo y lo sagrado. Madrid. Edit. Trotta.

De Freitas, A.J. (2012). “¿Agua, elemento importado en las cosmogonías griegas?”. Ponencia en el VI Coloquio AGON. Universidad de La Plata, Argentina.

De Freitas, A. J. (2012). "The language of the gods: Cosmogonic verbsand words". Talk delivered in the Research Seminar of the Department of Classics, Ohio State University.

Freitas, A. J. (2010). A reflection on Hesiod's Cosmos. Thebeginning of Greek Speculation, PhD Thesis, Universidade da Madeira.

Della Casa, R. (2010).” Una lectura simbólica de la permanencia/traslado de las divinidades de Hatti” en DavarLogos 9.2. Universidad Católica de Buenos Aires.

Delahoutre, Michel. (1990). "Sacralidad y estética en el arte de la India", en Tratado de antropología de lo sagrado. El hombre indoeuropeo y lo sagrado. Madrid. Ed. Trotta.

Driscoll, J. (1908). “Deity” The Catholic Encyclopedia. Vol. 4. New York: Robert Appleton Company.

Dietz Отто, E. (2003). Sumerian Grammar. Society of Biblical Literature Handbook of Oriental Studies. 71. El Enuma Elish. El poema de la creación”. Traducción de Luis Astey V. 
Fray Luis De León. (1974). Obras Completas Castellanas. "De los nombres de Cristo", BAC. Ed. preparada por el P.Félix García.

García Trabazo, J.V. (2002). Textos religiosos hititas. Mitos, plegarias y rituales. Colección: Biblioteca de Ciencias Bíblicas y Orientales, número 6. Edición bilingüe crítica. Madrid.

García, J.V. (2002). Textos hititas. Madrid. Ed. Trotta.

Heidegger. (1987) De camino al habla. Barcelona, Serbal-Guitard; en Qué es metafísica (1964) La Plata. U.N.L.P. Lo mismo en La pregunta por la técnica. (1958) Córdoba, Multi-Editora.

Heráclito. Fragmento 50, Diels.

Larroche, E. (1971) Catalogue des textes hitities. París, Klincksiek.

López Ruiz, C. (2010). When the Gods Were Born: Greek Cosmogonies and the Near East, Harvard University Press (2010).

Nono De Panópolis. Dionisíacas 4, 355 ss.

Ortega Y Gasset, J. (1963). Obras Completas. Ed. Revista de Occidente. Madrid. Pseudo Dionisio Areopagita (1995). Obras Completas: Los nombres de Dios. Jerarquia celeste. Jerarquía eclesiástica. Teología mistica. Cartas varias, Biblioteca de Autores Cristianos, Madrid. Rig Veda X.129.

Roberts, E. A y Pastor, B. (2009). «Deiw-». Diccionario etimológico indoeuropeo de la lengua española. Alianza. Madrid.

SAFo. Fragmento 17.

Santo Tomás (2001). Cuestión 13 de su Suma Teológica, Ed. BAC. Madrid.

Trías, T. (1997). “Pensar la Religión”. Seminario de Capri bajo la dirección de G. Vattimo y J. Derrida. Ediciones de la Flor, Buenos Aires.

West, M. L. (1966). Hesiod Theogony. Londres: Oxford University Press.

Weischedel, W. (1983). Der Gott der Philosophen. Wissenschaftliche Buchgesellschaft, Darmstadt. 